\title{
Duas histórias processuais memória e tortura na Operação Barriga Verde 1975*
}

Two memories processuais memoria and tortura on operation Barriga Verde 1975

\author{
Mateus Gamba Torres
}

\author{
Palavras-chave: \\ Operação Barriga Verde \\ Ditadura \\ Judiciário
}

Keywords:

Operation Green Belly

Dictatorship

Judicial

\begin{abstract}
Resumo: o presente artigo visa a trabalhar com alguns dos elementos que davam sustentação ao regime militar que, em meados da década de 1970, apenas começava a sentir os primeiros movimentos de crise que levariam à solução conciliatória da Nova República, na década seguinte. Compreende-se aqui que as decisões do judiciário militar e, particularmente, o processo judicial que se formou contra os acusados de reorganização do Partido Comunista em Santa Catarina como fruto da Operação Barriga Verde, extrapolavam o âmbito meramente do formalismo jurídico, envolvendo todo um imaginário construído ao longo de várias décadas e que se consubstanciava nos argumentos e sentenças proferidas. Nesse processo chamam a nossa atenção dois casos que demonstram as torturas e ilegalidades visíveis em documentos produzidos pelo próprio judiciário.
\end{abstract}

Abstract: This article aims to work with some of the elements that gave support to the military regime that in the mid 1970s was only beginning to feel the first crisis movements that would lead to the conciliatory solution of the New Republic in the following decade. It is understood here that the decisions of the military judiciary, and particularly the judicial process that was formed against those accused of reorganizing the Communist Party in Santa Catarina as a result of Operation Barriga Verde, extrapolated the scope merely of legal formalism, involving a whole imaginary built over several decades and consubstantiated in the arguments and sentences uttered. In this process we are drawn to two cases that demonstrate the torture and illegalities visible in documents produced by the judiciary itself.

Recebido em 30 de novembro de 2018. Aprovado em 27 de março de 2019.

\section{Folheando os jornais: milagre e liberdade}

No dia 4 de novembro de 1975, os leitores do jornal O Estado, de Florianópolis encontraram notícias que em nada fugiam do cotidiano da cidade, do Estado de Santa Catarina, do Brasil, nem ao menos no mundo. O Figueirense era "só entusiasmo" para enfrentar o Fluminense pela Copa Brasil no Estádio Orlando Escarpelli (O ESTADO, 1975. p. 1). Na capa do jornal era evidenciado o estado de saúde de Isabel Perón na Argentina, considerado pelos médicos de extrema gravidade (O ESTADO, 1975. p.1). Para o Estado de Santa Catarina o Governador Antônio Carlos Konder Reis, empossado no começo do ano de 1975, iria no dia seguinte encontrar-se com o presidente Ernesto Geisel para apresentar-lhe um projeto visando à implementação de um sistema nacional de gasodutos (O ESTADO, 1975, p.1) e, pela primeira vez no Brasil, o Imposto de Renda teria um desconto padrão de 20\% (O ESTADO, 1975, p.1). Franco, o ditador espanhol, dava seus últimos suspiros de vida, sendo submetido a diversas intervenções

\footnotetext{
* Texto dedicado ao jornalista, historiador e amigo Celso Martins, que, no livro "Os quatro cantos do Sol", trouxe à tona histórias humanas dessa operação repressiva e ditatorial eivada de tortura e autoritarismo. Celso Martins faleceu em 11 de outubro de 2018 . Pela sua coragem e pela luta constante pela democracia, a nossa singela homenagem. Celso Martins: "PRESENTE!".

** Professor Adjunto II do Departamento de História da Universidade de Brasília (UnB). Bacharel em Direito pela Universidade Federal de Santa Catarina (UFSC). Bacharel e licenciado em História pela Universidade do Estado de Santa Catarina (UDESC). Mestre em História do Tempo Presente pela Universidade do Estado de Santa Catarina (UDESC). Doutor em História pela Universidade Federal do Rio Grande do Sul (UFRGS). E-mail: gambatorres@gmail.com
} 
cirúrgicas (O ESTADO, 1975, p.1). O Banco do Brasil abria mais um concurso, para a alegria dos jovens que sonhavam em um emprego estável e bem remunerado para toda a vida até a aposentadoria (O ESTADO, 1975, p.9) -A propaganda governamental não poderia faltar com o slogan: "Sempre que há confiança entre o governo e seu povo, povo e governo governam. Governar é encurtar distâncias" (O ESTADO, 1975, p.1). Nos cinemas pelo Estado, estavam sendo exibidos gêneros da época como a pornochanchada $O$ Clube das Infiéis, no extinto Cine São José de Florianópolis, localizado ao lado da Catedral Metropolitana da Capital (O ESTADO, 1975, p.9). A notícia que poderia causar mais estranheza aos leitores em geral eram as críticas do senador Jarbas Passarinho, ex-ministro do Governo Costa e Silva, à censura estabelecida (O ESTADO, 1975, p.1). ${ }^{1}$

Apesar da tranquilidade aparente, àquela altura, estava-se em meio à chamada Operação Barriga Verde, deflagrada dias antes e que havia levado à prisão uma série de militantes políticos, em sua maioria ligados ao Partido Comunista Brasileiro $(\mathrm{PCB})^{2}$. Nos cárceres, os militantes já estavam passando por privações diversas: incomunicabilidade, medo, torturas, ameaças de fuzilamento. As prisões ocorreram no período da manhã do dia 04 de novembro de 1975; os militantes eram levados ao $63^{\circ}$ Batalhão de Infantaria, situado no bairro do Estreito. Relatos colhidos posteriormente transmitiam a impressão de que apenas os membros das famílias dos militantes e os deputados estaduais da oposição estavam a par do assunto e se manifestando sobre o considerado absurdo das prisões (sequestros) que estavam ocorrendo. Manifestações inflamadas de deputados do Movimento Democrático Brasileiro (MDB) não surtiram muito efeito, pois os militantes continuavam incomunicáveis e sendo torturados (MARTINS, 2006).

As torturas já começavam no próprio Batalhão de Infantaria. Porém, os considerados horrores ocorreram com mais intensidade em Curitiba: queimaduras, choques elétricos, paude- arara. Isso falando apenas das torturas físicas. No quesito psicologia também eram peritos os torturadores. Eram ouvidos pelos encarcerados gritos de crianças, lamentos de pessoas sendo torturadas. Durante a noite eram os encarcerados chamados mais de 20 ou 30 vezes, para prestar depoimento, impedindo-os de dormir (MARTINS, 2006).

A intenção dos militares era desbaratar a organização do Partido Comunista Brasileiro que possuía alguns de seus representantes atuando no Estado de Santa Catarina, a exemplo do que estava acontecendo em outros estados da Federação. A interpretação mais comum para a nova onda de repressão lançada pela ditadura aponta para a importância da vitória do MDB nas eleições de 1974 (CAMARA DOS DEPUTADOS, 2006). Com a derrota nas urnas, a ditadura militar tratou de tentar reforçar suas bases de legitimação social, apelando mais uma vez para a suposta ameaça que a esquerda poderia representar para o país. Como as organizações armadas haviam sido derrotadas, restava então enfocar um velho inimigo: o Partido Comunista Brasileiro.

Havia assim um contraste, entre a tranquilidade que era anunciada pelo jornal - que procurava mostrar como estava segura, próspera e tranquila a sociedade brasileira naquele momento-e as intensas movimentações repressivas que estavam lotando os cárceres de presos políticos. Artigos jornalísticos publicados no dia 04 de novembro de 1975 faziam referência à escalada democrática empreendida pelo Governo Geisel, ocorrida com a distensão política empreendida após o fortalecimento dos partidos, e da depuração necessária à estabilidade do regime. O governo Geisel era retratado como o baluarte da segurança, estabilidade e do esforço em estabelecer uma democracia plena no Brasil, responsável pela manutenção da desobstrução dos canais da normalidade institucional (D'ARAÚJO, CASTRO, 2002).

Nota-se que a ilegalidade já começava a ser cometida no momento da prisão dos acusados. A Justiça Militar, na figura do Juiz Auditor, de acordo com o Decreto-Lei no 898/69 - Lei de Segurança Nacional (BRASIL, 1969a), deveria ter sido comunicada através de ofício enviado pela autoridade policial que efetuou a prisão dos 
militantes. Em relação ao juiz, não poderia haver incomunicabilidade, ou seja, não informar qual o local do cárcere ou o paradeiro do detido. A prisão deveria ser imediatamente comunicada ao Juiz Auditor o que não ocorreu no caso da Operação Barriga Verde ${ }^{3}$.

Uma breve leitura do jornal $\mathrm{O}$ Estado daqueles dias próximos ao lançamento da Operação Barriga Verde parece demonstrar que havia uma ênfase em retratar a situação do país como harmônica e tranquila, principalmente no plano institucional, com eleições, partidos fortes, e o povo compreendendo o esforço do governo na manutenção da segurança interna. Um governo que não deseja o caos nem aceita prepotência. Parece até mesmo sarcástica tal afirmação quando no mesmo dia temos pessoas sendo torturadas e sequestradas, sem nenhum respaldo jurídico, ou acusação formada.

Para o leitor dos tempos atuais, folhear os jornais dos anos de 1970 levaria a perceber em pequenas, porém diversas colunas de notícias, em vários dias consecutivos, a presença de alguns personagens que não estariam, ou estariam muito pouco presentes nos jornais atuais, por exemplo, a Justiça Militar. A presença dessa justiça pode ser constatada em notícias como: "Promotor se pronuncia em processo de ex-deputado" (O ESTADO, 1975, p.11); "Justiça Militar em São Paulo absolveu mais 6" (O ESTADO, 1975); "Justiça Militar segue acusando 36 por atos de terrorismo" (O ESTADO, 1975); "Juiz Militar decreta prisão de 9 acusados por subversão" (O ESTADO, 1975, p11). A Justiça Militar, verifica-se, estava bastante presente no cotidiano da população, assim como o cinema, a televisão e as notícias sobre futebol.

A justiça militar à época era formada por um Juiz Auditor Civil. Este era o responsável por julgamentos de medidas acautelatórias, oitiva dos acusados e testemunhas, prisões preventivas, despachos sobre a validade dos atos processuais. Os outros juízes eram militares de carreira que nem ao menos precisavam ser bacharéis em direito, pois o requisito para ocupar o cargo era fazer parte da oficialidade militar, principalmente em postos de alta patente ${ }^{4}$.
Para muitos dos leitores dos jornais de Florianópolis aqueles tempos significavam ainda momentos de euforia, pois ainda estavam vivenciando os últimos momentos do chamado "milagre econômico", com seus fuscas novos que dominavam as ruas de Florianópolis e os eletrodomésticos que não poderiam deixar de estar na sala da dona de casa de classe média (O ESTADO, 1975). Televisões, aparelhos de barbear elétricos, depiladores femininos, rádios, amplificadores, toca-fitas, ícones da mudança, e da melhoria das condições de vida, ao menos das camadas médias da Capital. Apartamentos em Balneário Camboriú eram anunciados nos jornais para que a pujante classe média pudesse passar seus verões em contato com a natureza, ou apenas para investir seus ganhos crescentes (O ESTADO, 1975). Ao mesmo tempo o "milagre" mostrava sua face repressiva, e o processo da operação barriga verde é uma realidade sombria para aqueles que foram sequestrados pelos órgãos de repressão.

\section{O processo}

O processo da chamada Operação Barriga Verde foi aberto no ano de $1975^{5}$, tendo como seu embasamento legal a Lei de Segurança Nacional, além do Código de Processo Penal Militar de forma subsidiária, no que diz respeito ao procedimento a ser adotado (COGAN, 1976). Pode-se verificar que de acordo com tais leis, o processo, de forma genérica, possui duas fases: uma investigativa, pré-processual, onde são feitas investigações no sentido de verificar o cometimento de algum crime contra a segurança nacional e outra do processo propriamente dito, que começa na peça processual chamada denúncia, onde o procurador da justiça militar inicia a ação penal militar. ${ }^{6}$

$\mathrm{O}$ procedimento iniciava-se com a fase de investigação, quando uma autoridade policial, (Polícia Federal, Polícia Militar estadual, as Polícias do Exército, Marinha ou Aeronáutica, com seus serviços de informação, instala um inquérito. Qualquer uma destas polícias possuía autorização para investigar crimes contra a segurança nacional. 
Para a presidência do inquérito poderia ser nomeado um delegado, ou um inspetor no caso da justiça federal, ou um oficial no caso das polícias militares dos Estados ou das Forças Armadas. Grande poder possuía o encarregado do processo, de acordo com o Decreto-Lei no 898/69, em seu art. 59 , que prescrevia o seguinte:

Art. 59 - Durante as investigações policiais o indiciado poderá ser preso, pelo Encarregado do inquérito até trinta dias, comunicando-se a prisão à autoridade judiciária competente. Este prazo poderá ser prorrogado uma vez, mediante solicitação fundamentada do Encarregado do Inquérito à autoridade que o nomeou.

$\$ 1^{\circ}$ - O encarregado do inquérito poderá manter incomunicável o indiciado até dez dias, desde que a medida se torne necessária às averiguações policiais militares. (BRASIL, 1969a).

Ou seja, percebe-se que poderia o indiciado ser preso pelo próprio encarregado, bastando apenas comunicar a prisão para a autoridade judiciária, deixando o investigado incomunicável, com relação a todas as outras pessoas. Após a conclusão do inquérito, era realizado um relatório minucioso de todas as provas encontradas contra os indiciados do inquérito. $\mathrm{O}$ inquérito concluído era então encaminhado ao Juiz Auditor Militar da região na qual os crimes haviam sido supostamente cometidos. O Juiz Auditor Militar encaminhava os autos ao Procurador da Justiça Militar, membro do Ministério Público Militar, responsável pela deflagração da Ação Penal Militar, pelas práticas dos crimes contra a segurança nacional.

O procurador da Justiça Militar devolveria os autos para o Juiz Auditor e, em caso de denúncia, o juiz poderia ou não recebê-la $l a^{7}$, fazendo-o positivamente no caso de que realmente houvesse indícios de crime e o procedimento adotado até aquele momento estivesse de acordo com a lei. O Juiz Auditor era o único juiz civil que pertencia ao Conselho Permanente de Justiça Militar, que era o Órgão Judicial responsável pelo julgamento dos civis e de não oficiais (ALVES, 2005). Tal jurisdição era formada no seguinte modelo, estabelecido pelo Decreto $\mathrm{n}^{\circ}$. 1.003 , no parágrafo $2^{\circ}$ do art. 13: "[...] os Conselhos Permanentes de Justiça serão constituídos do auditor, de um oficial superior, como presidente, e de três oficiais até o pôsto de capitão ou capitão-tenente" (BRASIL, 1969c). Conforme o art. 62 da Lei de Segurança Nacional, o Juiz Auditor ao receber a denúncia tinha a obrigação de citar o denunciado, para que ele fosse processado e julgado. Caso ele não conseguisse ser citado por estar em lugar incerto ou não sabido, deveria ser citado por edital (BRASIL, 1969a).

Após tudo isso, era marcada uma audiência para se ouvir as testemunhas, debates orais e sentença. As testemunhas de acusação, em número de até três, já eram descritas na denúncia, enquanto a defesa poderia arrolar duas testemunhas para cada acusado. Em caso de ausência das testemunhas de defesa à audiência de instrução e julgamento, marcada pelo Juiz Auditor, seria formalmente considerado que o Advogado de defesa desistira de ouvi-las. Na mesma audiência era dada a palavra para o advogado de defesa e para o Procurador de Justiça Militar, para que estes fizessem a sustentação oral das suas teses. Posteriormente, era proferida sentença em audiência. O Ministério Público, em caso de absolvição, deveria obrigatoriamente recorrer para o Superior Tribunal Militar (BRASIL, 1969a).

Percebe-se que todo o processo é realmente feito para dar uma vantagem ao Procurador da Justiça Militar, pois se as testemunhas de defesa devem comparecer independentemente de intimação, não estavam por lei obrigadas a comparecer; e, caso não comparecessem, entendia-se que o advogado de defesa tivesse delas desistido.

Além disso, o Ministério Público obrigatoriamente deveria recorrer da sentença que viesse a absolver os acusados, não obrigando os advogados de defesa a recorrer, ou seja, em caso de condenação a lei dá a entender que foi feito justiça e, em caso de absolvição, entende-se que algo errado ocorreu e deve ser corrigido pelos Tribunais Superiores.

\section{Os réus}

O processo judicial criminal militar que foi gerado como consequência da deflagração da 
Operação Barriga Verde, de n 749 de 1976 e que, que no Superior Tribunal Militar pode ser encontrado através do número do seu Recurso, interposto pelo Ministério Público Militar e por alguns dos réus para que fosse revista sua pena, Apelação n ${ }^{\circ}$ 42.031, de 1978, servirá de base para analisarmos de que forma eram elaborados esses processos e a carga simbólica que traziam os discursos que eram elaborados em torno de dois integrantes do Partido Comunista Brasileiro pelas autoridades judiciais, procuradores de justiça, advogados, encarregados do inquérito e outros possíveis atores que estivessem envolvidos com o processo. O processo é composto de 12 volumes, totalizando mais de 3 mil páginas (BRASIL, 1978).

O processo está arquivado na Seção de Arquivo, órgão vinculado à Diretoria de Documentação e Divulgação do Superior Tribunal Militar, em Brasília. O processo iniciouse na primeira instância da Justiça Militar, na $5^{\circ}$ Circunscrição da Justiça Militar situada no Estado do Paraná, pois era atribuição deste Conselho julgar todos os processos criminais militares relativos à Segurança Nacional ocorridos nos Estados do Paraná e Santa Catarina.

São 42 réus processados, através do Representante do Ministério Público Militar, o chamado Procurador da Justiça Militar que, ao receber das mãos do Juiz Auditor Militar o inquérito n $49 / 75$ concluído, e vislumbrando a prática do crime do art. 43 da Lei de Segurança Nacional (BRASIL, 1969a), ingressou com Ação Penal Militar, na função de representante da lei e fiscal de sua execução conforme o art. 34 do Código de Processo Penal Militar. Código este que foi elaborado para descrever o procedimento a ser tomado por todos os participantes do processo (BRASIL, 1969b)

Fazendo uma pequena análise estatística do processo, nota-se a presença de 31 réus com idade entre 25 e 40 anos de idade, sendo os outros 11 com idade acima de 40 anos, com limite de 60 anos. Dentre todos os réus, dois são mulheres e três no quesito cor são considerados pardos pelo encarregado do inquérito. Destes réus, ainda devese citar que um foi julgado à revelia, pois estava em lugar incerto e não sabido, de acordo com o inquérito.
Desde o começo do processo, praticamente todos os acusados foram presos. Os primeiros a serem presos, assim o ficaram desde 04 de novembro de 1975, estando incomunicáveis ao menos até 14 de novembro de 1975 (BRASIL, 1978), inclusive incomunicáveis em relação à autoridade judiciária, o que não era permitido de acordo com a própria LSN, em seu art. 59. A incomunicabilidade, de acordo com a doutrina jurídica da época, não era permitida nem em relação ao advogado. Ou seja, mesmo declarado incomunicável pelo encarregado do processo e tal prisão sendo encaminhada ao juiz e este ainda mantivesse a incomunicabilidade, teria o réu direito a manter contato com seu advogado.

Esta incomunicabilidade não impede a comunicação com seu advogado, conforme dispõe o art. 89, III, do Estatuto da Ordem dos Advogados do Brasil (lei no 4.215, de 27. 4. 1963): "São direitos do advogado - comunicar-se pessoal e reservadamente, com os seus clientes, ainda quando estes se achem presos ou detidos em estabelecimento civil ou militar, mesmo incomunicável. (COGAN, 1976).

Inclusive de acordo com a própria Constituição Federal de 1967, com redação dada pela Emenda no 1 de 1969, a prisão deve ser imediatamente comunicada ao juiz, o que não consta no processo. Conforme art. 153, parágrafo 12 da citada Constituição:

Ninguém será preso senão em flagrante delito ou por ordem escrita de autoridade competente. A lei disporá sôbre a prestação de fiança. A prisão ou detenção de qualquer pessoa será imediatamente comunicada ao juiz competente, que relaxará, se não fôr legal. (BRASIL, 1967).

Em nenhum documento no processo, demonstra-se a comunicação à autoridade judiciária, mas sim apenas depois de dez dias para o Subcomandante do $4^{\circ}$ Batalhão Policial Militar de Santa Catarina, no dia 14 de novembro de 1975, tendo em vista as prisões terem ocorrido no dia 04 de novembro de 1975 e estarem os presos sob sua custódia. Ou seja, ilegalmente, o encarregado 
do Inquérito decretou as prisões juntamente com a incomunicabilidade dos réus (BRASIL, 1969a). Além disso, quem determinou a quebra da incomunicabilidade foi o próprio encarregado do inquérito, e nada disso foi comunicado ao Juiz Auditor, como determina a lei, mas sim apenas para um Major Comandante do $4^{\circ}$ BPM de Santa Catarina, que estava com os presos sob sua custódia (BRASIL, 1978). Foi inclusive determinado que os réus continuassem presos segundo o Juiz,

\begin{abstract}
Senhor Major
Comunico a $\mathrm{V}^{\text {a }}$ Sra ${ }^{\mathrm{a}}$ que nesta data foi suspensa a incomunicabilidade dos presos T.G., A.V., M.C.F.R.J.M., C.P., V.L., C.M.C ${ }^{8}$, que foram presos em data de 4 de corrente mês, indiciados nos autos do inquérito policial 49/75, instaurado por esta Superintendência, como incursos nas penas dos artigos 39, 43, 45, inciso II e VI do Decreto Lei 898/69. Esclareço, outrossim, que os nominados deverão continuar presos, a disposição desta autoridade processante. (BRASIL, 1978).
\end{abstract}

De acordo com os autos do processo, a primeira menção ao Juiz Auditor Militar foi feita na página 172 no dia 04 de dezembro de 1975. Referese a um pedido de prorrogação de prazo para a conclusão do inquérito feito pelo encarregado, por mais 30 dias, para o Superintendente do Departamento da Polícia Federal que o nomeou para presidir o inquérito, pedindo para que este comunique ao Juiz Auditor tal prorrogação após a autorização dada pelo Superintendente.

$\mathrm{Na}$ conformidade com o que preceitua o art. 59 do Decreto Lei 898/69, solicitese ao Sr. Superintendente Regional da DPF/SC, prorrogação, por mais trinta dias, do prazo para a ultimação do presente inquérito policial. Comunique-se ao MM. Dr. Juiz Auditor da $5^{\text {a }}$ CJM, a prorrogação do prazo, tão logo autorizada pelo Superintendente Regional da DPF. Prossiga-se nos demais atos legais. (BRASIL, 1978).

Durante as investigações policiais, 11 dos acusados foram colocados em liberdade provisória pelo encarregado do inquérito. Tais alvarás de soltura foram elaborados pelo encarregado do inquérito, pois, ao dispor do poder de prender, tecnicamente, tinha o poder de soltar. Todavia verifica-se mais uma ilegalidade. A soltura destes 11 presos foi realizada no dia 02 de janeiro de 1976; porém, quando o encarregado solicitou a prorrogação do prazo para a conclusão das investigações, não solicitou em requerimento à sua autoridade superior a manutenção da prisão dos acusados, apenas a prorrogação do prazo para investigação, nada mencionando a respeito da prisão dos acusados. O requerimento foi apenas de prorrogação do prazo, talvez por considerar que apenas a menção ao art. 59 da LSN já o autorizava a efetuar a prisão por mais 30 dias dos acusados, sem ao menos requerer a prorrogação da prisão. $\mathrm{E}$ mais, de acordo com a doutrina jurídica da época, a prisão somente poderia ser prorrogada por no máximo 20 dias.

Estabelece, ainda, o Código de Processo Penal Militar que o indiciado poderá ficar detido, durante as investigações policiais, até trinta dias, comunicandose a detenção à autoridade judiciária competente. Esse prazo poderá ser prorrogado por mais vinte dias, pelo comandante da Região, Distrito Naval ou Zona Aérea, mediante solicitação fundamentada do encarregado do inquérito por via hierárquica (art. 18). Em se tratando, porém, de crime contra a Segurança Nacional, o prazo de trinta é prorrogável, por mais uma vez por intermédio da autoridade que determinou a sua instauração. Calandose o tempo sobre o espaço de tempo, deve-se entender, em consonância com o disposto no Código de Processo Penal Militar, que ele é de vinte dias". (COGAN, 1976, p. 82).

Também que não houve resposta do Superintendente sobre o requerimento elaborado pelo encarregado, pelo menos não consta no processo. E não existe nem uma cópia de qualquer ofício, com uma assinatura ou recebimento do juiz, provando que este tinha consciência de que havia pessoas presas na carceragem da Polícia Federal, no $63^{\circ}$ Batalhão de Infantaria ou ainda no $4^{\circ}$ Batalhão da Polícia Militar. Além dos acusados, foram também 
ouvidas 4 testemunhas. Com relação apenas ao inquérito realizado com o objetivo de fundamentar o ingresso da ação penal por parte dos Procuradores da Justiça Militar foram 208 páginas de inquérito elaborado na Polícia Federal em Florianópolis.

Duas ilegalidades são vislumbradas analisando o processo da Operação Barriga Verde: a incomunicabilidade dos réus com relação à autoridade judiciária competente e a prorrogação acima do prazo de 20 dias, isso de acordo com a doutrina jurídica à época (COGAN, 1976).

Quem poderia sanar estas ilegalidades e relaxaraprisãodosacusados? A autoridadejudiciária, o Juiz Auditor Militar. Após o interrogatório dos réus e a oitiva das quatro testemunhas, foi realizado pelo encarregado do Processo o relatório final do inquérito. Minuciosamente elaborado, (conforme a versão do encarregado) o inquérito inteiro foi encaminhado ao Juiz Auditor Militar, com o pedido de prisão preventiva de todos os acusados que já estavam presos sob custódia da Polícia Militar por determinação do encarregado, pois, de acordo com a LSN, seu poder sobre a liberdade dos presos somente durava até o final do inquérito e, caso o Conselho Permanente de Justiça considerasse conveniente manter os réus presos, deveria despachar neste sentido determinando a prisão preventiva. A prisão preventiva poderia ser decretada nas seguintes hipóteses.

Para que a prisão preventiva seja decretada é preciso que, além de prova do fato delituoso e indícios suficientes da autoria, a medida justifique-se como: a) garantia da ordem pública; b) conveniência da instrução criminal; c) periculosidade do indiciado ou acusado; d) segurança da aplicação da lei penal militar; e) exigência da manutenção das normas e princípios de hierarquia e disciplinas militares, quando ficarem ameaçados ou atingidos com a liberdade do indiciado ou acusado. (COGAN, 1976).

Não dependia, porém, o Juiz Auditor Militar, de decisão do Conselho para determinar o relaxamento da prisão dos acusados em caso de ilegalidade desta. De acordo com o Código de
Processo Penal Militar, em seu art, 46, item III, seria da competência do auditor, "[...] relaxar, em despacho fundamentado, a prisão que lhe for comunicada por autoridade encarregada de investigado policiais" (BRASIL, 1969b).

Mas isso não fez o Juiz Auditor da Justiça Militar. Tinha ele o poder de, ao ver tamanhas ilegalidades, relaxar imediatamente as prisões, conforme o art. 46 da Lei de Segurança Nacional (BRASIL, 1969a), e ainda de acordo com parágrafo 12, do art. 153, da própria Constituição Federal de 1967 (BRASIL, 1967). Mas preferiu primeiramente encaminhar os autos ao Ministério Público para parecer, enquanto os réus, em número de 31, continuavam presos. Posteriormente, o Juiz Auditor apenas recebeu a denúncia e marcou a data do julgamento do pedido de prisão preventiva elaborado pelo encarregado e que deveria ser analisado pelo Conselho Permanente de Justiça, para os meses de fevereiro a abril de 1976, tendo em vista, que marcou audiências em datas diferentes para os réus, dividindo-os em grupos. Começa o seu despacho o juiz, afirmando estarem as alegações "revestidas das formalidade legais" e, assim, "recebo a denúncia”. E conclui:

Sejam estes autos apresentados na audiência do Conselho Permanente de Justiça para o Exército desta auditoria, designada para o dia 19 do mês em curso, para apreciação do pedido de decretação de prisão preventiva constante nos autos. (BRASIL, 1978).

O parecer do Ministério Público opinava pela manutenção da prisão dos acusados que ainda estavam encarcerados por determinação do encarregado do Inquérito, um Inspetor da Polícia Federal (BRASIL, 1978). Após o despacho do Juiz Auditor, determinando as audiências, este,Batalhcersa haveria desistido de ouv manda que fosse feita a juntada dos antecedentes criminais dos acusados. Segundo apresentado pelo escrivão, apenas seis possuíam processos ou condenações. Vislumbra-se que todos estes seis possuíam antecedentes criminais referentes a práticas de crimes contra a segurança nacional ou crimes políticos, e nenhuma infração penal comum. 
Diversos pedidos de relaxamento de prisão começaram a ser juntados ao processo pelos advogados dos acusados, após a designação das audiências. Tentam os advogados de todas as formas relaxar a prisão de seus clientes, utilizam como argumento que os acusados cumprem os requisitos do art. 257 do Código de Processo Penal Militar demonstrando a desnecessidade de continuarem presos.

Art. 257. O juiz deixará de decretar a prisão preventiva, quando, por qualquer circunstância evidente dos autos, ou pela profissão, condições de vida ou interêsse do indiciado ou acusado, presumir que êste não fuja, nem exerça influência em testemunha ou perito, nem impeça ou perturbe, de qualquer modo, a ação da justiça. (BRASIL, 1969b).

De acordo com os advogados o fato de os acusados serem profissionais, trabalhadores e dedicados à família deveria servir para soltá-los. "Os documentos inclusos, porém, demonstram que todos os réus são homens dedicados ao trabalho honesto, com família constituída merecendo por isso mesmo aguardar em liberdade o julgamento da causa" (BRASIL, 1976).

\section{Os Réus e as prisões}

Em geral os acusados são membros da classe média e portadores do que podemos chamar de um capital cultural valorizado pela sociedade, e este argumento não deixa de ser utilizado por seus advogados.

Há médico, há advogados, há engenheiro, há dentistas, há funcionários públicos, há estudantes e há operários, todos como resultará provado pelo exame que se dignar levar a efeito os doutos magistrados dessa Casa de Justiça Castrense, tem domicílio certo, profissão definida, e, nenhum, é de ressaltar, tem o mínimo de periculosidade. (BRASIL, 1976, p. 1086).

Além disso, em diversas petições demonstram as torturas sofridas por seus clientes e a situação médica em que se encontram após tais torturas, inclusive juntando cartas que relatam a situação em que foram presos.

As prisões ocorreram dia 4 de novembro pela manhã. Antes disso alguns estávamos sendo seguidos por elementos estranhos. Falei prisões, mas na realidade foram seqüestros. Sem qualquer ordem de prisão ou aviso aos familiares. As nossas casas foram invadidas ilegalmente. Foram retirados sem ordem livros, e objetos de uso pessoal, não só dos que estavam nas mãos da repressão, mas também dos familiares. (BRASIL, 1978, 1086).

Além dos argumentos que expõem referente ao Código Processual Militar, e da desnecessidade das prisões, demonstram que tais prisões são um risco para a saúde de seus clientes.

Que está preso a meses, e doente antes, seu estado de saúde dia-a-dia mais se agrava, e como não tratamento na Colônia Penal, como sua saúde exige, por certo, caso não seja tomada uma providência imediata para ficar em liberdade e em companhia de seus familiares, sucumbirá. Que a documentação médica em anexo prova sê-lo cardíaco em grau máximo, e está definhando em cela, não obstante, é verdade o mínimo possível de atendimento que pode e é, quiçá, prestado e ele, o acusado, poderá morrer no cárcere, o que não interesse a ninguém, menos ainda a justiça, daí, doente como se encontra merece uma atenção especial e não adianta ser internado em hospitais (que nem existe em condições de atendimento especializado), que em nada resolveria, daí, porque requer seja relaxada sua prisão, como dever e princípio não só de justiça mas também de humanidade. (BRASIL, 1978, p. 1235, grifos do autor).

E como há poucos meses havia ocorrido o caso Herzog ${ }^{9}$, os advogados deixavam claro que isso poderia ocorrer novamente e a repercussão seria também grande e desagradável para a Justiça Militar. 
Não é para dramatizar, menos ainda para comover os doutos membros desta casa, mas é dever e obrigação dos advogados, deixar os julgadores a par dos acontecimentos, e isso é feito agora, sem qualquer demagogia, sem qualquer outra intenção senão a de que urge relaxar a prisão dos quatro evitando que no amanhã, os jornais publiquem a morte de mais um preso, fato sempre desagradável a todos. (BRASIL, 1978, p. 1248).

Citam jornais da época em que pessoas que estavam sendo acusadas do mesmo crime no Estado de São Paulo estavam tendo suas prisões preventivas revogadas (BRASIL, 1978, p. 1249). Após estas diversas petições com pedido de relaxamento de prisão e, consequentemente, de não decretação da prisão preventiva; enfim, chegaram as datas em que ocorreram as audiências do Conselho Permanente de Justiça (BRASIL, 1978, p. 1297).

Conforme a ata do dia 19 de fevereiro de 1976, reuniu-se o Conselho Permanente da Justiça Militar da $5^{a}$ Circunscrição da Justiça Militar, para decidir sobre o pedido de prisão preventiva elaborado pelo encarregado do Inquérito e ratificado pelo representante do Ministério Público. Os advogados fizeram sustentação oral dos pedidos de relaxamento de prisão, requerendo a não decretação da prisão preventiva dos acusados.

Conforme decidiu o Conselho neste dia, em nada adiantou a argumentação dos advogados, o Conselho não só deferiu o pedido de prisão preventiva de todos os 31 acusados, como mandou prender preventivamente um dos acusados que já havia sido solto pelo encarcerado. Isso era perfeitamente permitido em lei, conforme o art. 254 do Código de Processo Penal Militar; porém, verifica-se que os juízes do Conselho estavam sendo mais rigorosos do que um funcionário da Polícia Federal e do que o Representante do Ministério Público Militar, aos quais cabia a missão de sustentar o rigor da acusação (BRASIL, 1969b).
Tudo isso por unanimidade de votos e após reunirem-se em sala secreta para a tomada de decisão. Percebe-se também que a decisão não foi fundamentada imediatamente naquele momento, somente sendo juntada aos autos do processo quase um mês depois. A fundamentação para decretação da prisão preventiva não era obrigatória, de acordo o Código de Processo Penal Militar e a Constituição de 1967, com a modificação inserida pela Emenda $\mathrm{n}^{\circ} 1$ de 1969. Nota-se o movimento de manter presos os acusados, denotando um clima de medo da subversão. Determinou o Conselho, ainda, que fosse realizada inspeção médica nos quatro acusados que estavam afirmando estar doentes e precisando de tratamento (BRASIL, 1978, p. 1298).

O Ministério Público Militar, após a apresentação dos laudos médicos, poderia e deveria, conforme sua condição de fiscal da lei, mandar apurar as torturas mencionadas pelos acusados por meio de seus advogados e documentos por eles juntados, mas sequer se manifestou sobre o caso ou quedou-se a apurar as denúncias de tortura e maus tratos sofridos pelos réus (BRASIL, 1969).

A próxima fase do processo é o interrogatório, agora perante a autoridade judiciária e não mais policial, na qual são feitas algumas perguntas já preestabelecidas em lei, e mais algum esclarecimento que queira fazer o acusado ou responder a alguma pergunta realizada pelo Juiz Auditor, juntamente com o Procurador do Ministério Público Militar, e o advogado de defesa do réu (BRASIL, 1978, p. 1368). É o primeiro momento do processo em que há a possibilidade de o réu falar sua versão dos fatos para o Juiz Auditor Militar, pois até aquele momento o que disse no processo foi por meio de seus advogados. Já neste momento nota-se uma discrepância imensa do depoimento prestado na carceragem da Polícia Federal (BRASIL, 1978, p. 1364).

Deviam, e isso fizeram os advogados, após o interrogatório dos réus, juntar uma defesa prévia, requerendo tudo de direito: soltura, colheita de provas, juntada de documentos e algumas afirmações no sentido de provar a inocência dos réus. A tese definitiva da defesa e de acusação é realizada em alegações finais, como última fase antes 
do julgamento do processo, na qual, em documento escrito, o Procurador de Justiça Militar e os advogados de defesa expõem suas teses. A acusação e a defesa ainda se encontraram na audiência de julgamento dos réus, na qual o Procurador de Justiça e os advogados dispunham de uma hora para apresentação de razões orais, conforme art. 70 do Decreto nº 898/69 (BRASIL, 1969a).

\section{Dois réus: duas histórias processuais}

O processo traz ainda algumas histórias, que aqui chamaremos de processuais, com relação às acusações sofridas pelos réus, seus depoimentos, particularidades nas defesas, ou seja, como o processo se desenvolveu sob o ponto de vista da experiência do processado. Foram escolhidos dois réus que nos chamaram mais atenção: T.G., "funcionário" do partido e J. S. N., comunista arrependido.

\section{A) T.G.: o "funcionário"}

Considerado perigoso, T.G. era também cogitado como o profissional a serviço do Comando Central do Partido Comunista em Santa Catarina, Segundo o Procurador de Justiça Militar, responsável pelo aliciamento de militantes e contribuições financeiras. Sendo todas as afirmativas baseadas no inquérito policial, o Procurador toma a descrição dos fatos pelo acusado, em sua confissão, expostas de forma minuciosa. Cabe aqui alertar, uma vez mais, que tais informações foram obtidas provavelmente através de tortura ou outro tipo de coação.

Em Santa Catarina, participou de inúmeras reuniões do $\mathrm{CE} / \mathrm{PCB} / \mathrm{SC}$, Comitês Estaduais e Organizações de Base, mantendo diversos contatos pessoais com os militantes $\mathrm{e}$ colaboradores do referido Estado, no interesse de reestruturação dos quadros do PCB e obtenção de recursos financeiros para o partido clandestino. Viajou para a Rússia em 1963. (BRASIL, 1978, p. 26).

Foi requerida sua prisão preventiva pelo Encarregado do Inquérito por ser considerado elemento estrangeiro e perigosíssimo à Segurança Nacional. Em parecer elaborado pelo Procurador de Justiça, manifestando-se sobre o pedido de prisão preventiva realizado pelo Encarregado do Inquérito, o representante do Ministério Público, resume a personalidade do agente como nociva à segurança nacional e, por isso, o réu deve ser mantido preso. "[...] demonstrando a alta periculosidade deste denunciado, que se dedica exclusivamente à subversão, pelo que sua liberdade seria danosa à segurança nacional, à instrução criminal e à provável aplicação da pena" (BRASIL, 1978, p. 495).

A segurança nacional é um conceito fechado, através do qual o Estado descreve os riscos a que estaria submetida a sociedade, o maior deles a subversão da ordem por movimentos como o comunismo internacional. Elementos como T.G., juntamente com outros que, deliberadamente, atuavam contra a segurança nacional, poderiam criar um clima de conflitos no seio da nacionalidade, pela reorganização de um partido clandestino. $\mathrm{O}$ "funcionário" do partido forneceu - ou confessou - as informações previamente desejadas pelo Encarregado do Inquérito, mediante diversas sevícias e ameaças no cárcere, conforme carta de M.C.F.:

Quando estava na cela, sozinho, ouvi várias ameaças a T.G. que era romeno e poderiam matá-lo como já tinham feito com tantos outros e que ninguém iria reclamar; que iam entregá-lo ao esquadrão da morte etc. [...].

Disseram que iram trazer a esposa e filha de T.G., para que ele dissesse o que sabia. Em vista dessa ameaça T.G. que já ouvira de N.C. o que sua família havia sofrido, ficou abalado e caiu em profunda depressão. T.G. achava que a única maneira de evitar que sua família fosse torturada era a sua morte [...]. (BRASIL, 1978, p. 1092).

Sua vida corria grave risco, isso atestado pelos companheiros de cárcere. Após uma tentativa frustrada de suicídio (T.G., bateu diversas vezes sua cabeça na parede), escreveu um colega de infortúnio: 
Felizmente a tentativa não foi fatal e está vivo ainda até hoje, embora tenhamos certeza de que sua vida corre perigo, pois sabemos que quando não interessar mais aos órgãos de segurança eles o matarão. Já fizeram inclusive várias propostas de fuga para encontrar um pretexto de assassiná-lo. É preciso que todos se mantenham vigilantes. (BRASIL, 1978, p. 1092).

Em seu interrogatório judicial, perante o Conselho, o Ministério Público e seus advogados, alegou que, depois de preso no dia 04 de novembro de 1975 em São José, foi levado para Curitiba, onde foi torturado e, assim, obrigado a assinar o depoimento apresentado por Dr. L. Contou que era funcionário do Sindicato dos Metalúrgicos de São Paulo, onde foi preso, em 1965, ficando encarcerado por quatro meses, sendo processado pela Justiça Militar paulista. Mesmo sendo absolvido, teve dificuldade para arranjar emprego, vindo morar em Florianópolis; e, para não ser importunado, "[...] através de 'Paulo' um vendedor de livros, conseguiu um registro de nascimento falso com o nome de O.M.S.; que, com esse nome tirou o título de eleitor." (BRASIL, 1978, p. 1092)

Sua suspeita viagem à Rússia teria ocorrido para visita a antepassados, pois veio da Romênia ao Brasil em 1926, deixando lá, tios e sobrinhos. Com relação ao apelido de R., devia-se ao fato de ter sido esportista e jogar na posição de goleiro, pois em Minas Gerais existia um R. que era careca como o interrogando. Em momento algum dos autos, a não ser na fase do interrogatório, o acusado afirmou ser membro ou integrante do $\mathrm{PCB}$, mas isso foi declarado por alguns dos outros presos que o reconheceram como aliciador e arrecadador de dinheiro para o Partido.

Conseguiu remoção para um presídio no Estado de São Paulo, o presídio do Hipódromo, para receber assistência de sua família, depois de um ano e meio preso em Florianópolis (BRASIL, 1978, p. 2718).

Em alegações finais do Ministério Público Militar, o Procurador de Justiça resumiu de modo sucinto os fatos criminais praticados. Todavia, com relação a T.G., não deixou de apresentá-lo como o principal responsável por todas as operações que estavam sendo investigadas. O procurador procurou demonstrar a periculosidade das ideias comunistas, dada a facilidade para aliciar trabalhadores com astúcia, como o fazia T.G.

[...] sendo que, para T.G., será pedida uma pena maior que aos demais, pois foi o elemento que, enviado pelo Comitê Central do PCB à SC, conseguiu reorganizar e fazer funcionar o citado partido clandestino com a realização de inúmeras reuniões. (BRASIL, 1978, p. 3234).

Nota-se a responsabilidade que é colocada a um elemento comunista; portanto, talvez sofreu mais T.G. do que outros, considerado o grande inimigo. O profissional, aquele que traria a discórdia entre as classes e o ateísmo para as famílias. Um elemento estrangeiro que não conhecia as tradições brasileiras e que, por isso, deveria ser combatido.

Em suas alegações finais o advogado de defesa debruçou-se sobre as provas colhidas na fase judicial, que não o comprometiam o acusado. A exposição de sua vida às autoridades judiciárias, segundo seu advogado, não teria demonstrado nenhuma conduta desabonadora. A defesa ainda informou que a condenação de T.G. em São Paulo a quatro anos de reclusão pelo mesmo crime, foi reformada pelo Superior Tribunal Militar, que o absolveu.

Por fim, o advogado de defesa sustentou que as acusações sofridas pelo acusado não se confirmaram na fase de instrução processual: os demais corréus "[...] não confirmam, por sua vez, as declarações prestadas no inquérito, o que, por seu turno, invalidam essas declarações, que seriam a base da acusação, segundo a denúncia" (BRASIL, 1978, p. 3313).

Conseguiu T.G. o direito de ser posto em liberdade três meses antes seu julgamento. Para os Magistrados, “[...] considerando o tempo de prisão preventiva e outras circunstâncias de família e idade", ele já havia cumprido dois anos e 22 dias de prisão e, de acordo, com a lei, a pena base para a sua possível condenação seria a de dois anos (BRASIL, 1978, p. 3388). 
Mas, para os Juízes, não restavam dúvidas sobre T.G. ser o responsável direto pela estruturação do PCB em Santa Catarina. "Encontramos em T.G., ou mais precisamente O.M.S., nome do qual se utilizava, ou ainda pelo codinome de R., a figura de real destaque no desenrolar das atividades ilegais postas em prática no Estado de Santa Catarina." (BRASIL, 1978, p. 3483). Vincularam sua imagem a de um "funcionário" do Partido Comunista Brasileiro que agia profissionalmente e que, "[...] cumprindo determinações do comitê central do partido comunista, iniciou um trabalho constante com a finalidade de estruturar o partido comunista no estado de Santa Catarina, pela criação do Comitê Estadual, Municipal e Organização de Base" (BRASIL, 1978, p. 3483). Tudo isso "[...] aliciando outros adeptos, ao mesmo tempo em que propagava a idéia subversiva de organização do partido naquele Estado" (BRASIL, 1978, p. 3483).

Ao final foi condenado a quatro anos de prisão pelo Conselho Permanente de Justiça. Houve recurso da decisão, porém, antes do julgamento do recurso, T.G. foi libertado condicionalmente pelo Juiz Auditor C.A.M.R. em $1^{\circ}$ de junho de 1979. T.G. como os outros réus não chegou a ter seu recurso julgado posto que seu processo foi extinto com o advento da Lei no 6.683, de 28 de agosto de 1979 Lei de Anistia (BRASIL, 1979).

\section{B) J.S.N.: o "comunista arrependido"}

Dentre as histórias que se encontram presentes nos autos, uma chama a atenção pela diferença de atitude do réu com relação ao Conselho de Justiça Militar e também com relação à sua posição durante a fase judicial, no afã de defender a sua inocência. Este acusado é J.S.N., advogado do Sindicato dos Mineiros de Criciúma, cujas declarações demonstraram arrependimento em relação à sua militância.

$\mathrm{Na}$ fase do inquérito policial, aparecem descritas declarações supostamente suas, segundo as quais participou de reuniões do PCB para tratar de assuntos relativos às chapas a serem formadas pelos comunistas nas eleições naquele sindicato. Em diversas reuniões posteriormente realizadas para tratar de assuntos relativos ao sindicato, ficou clara a posição do acusado com relação novamente às chapas a serem formadas para a eleição no sindicado, pois "[...] o interesse do interrogado era de que estes candidatos fossem aqueles que ele melhor conhecia e que tivessem militância no partido comunista". (BRASIL, 1978, 115) Também foi descrita a participação do acusado em reuniões relativas a tratar de candidaturas a vereador do MDB, com o apoio no PCB.

Que nesta reunião o assunto foi a
candidatura de R.F. para vereador pelo
MDB; que tanto os interrogados quanto
os demais desejavam que R.F. fosse
eleito porque assim melhor fortaleceria
a posição do PCB dentro do MDB em
Criciúma. (BRASIL, 1978, p. 115).

Por fim, participou de uma reunião em que apenas foram tratados assuntos relativos ao PCB e como poderia ser reorganizado na cidade Criciúma, demonstrando uma participação direta do acusado no partido, pelo menos na descrição do inquérito.

Que nesta reunião foram tratados assuntos relativos a situação do $\mathrm{PCB}$ em Criciúma, ficando deliberado que todos os participantes deveriam se esmerarem para alicarem [sic] mais elementos para o PCB, assim como reestruturarem o Partido Comunista, que se encontra totalmente desorganizado; que $\mathrm{o}$ interrogado apenas se recorda de haver participado de uma reunião do $\mathrm{PCB}$ na residência de R.F. (BRASIL, 1978, p. 115).

Segundo consta em suas confissões, deixou o partido em 1971. Em sua residência foram encontrados diversos jornais e revistas "comprometedores", pelas quais o acusado foi obrigado a se explicar:

[...] o exemplar da revista "União Soviética" $\mathrm{n}^{\circ} 136$, adquiriu numa livraria na cidade Porto Alegre/RS, em 1963; que os jornais "O Ruista" também apreendidos, são dos tempos em que o acusado era estudante secundário no Rio Grande do Sul, sendo que o jornal "O Estudante" era guardado porque continha uma poesia de sua autoria; 
que as revistas "História do Século 20" adquiriu a fim de facilitar pesquisas a serem feitas por seus filhos. (BRASIL, 1978, p. 116)

Afora a revista da União Soviética, os outros títulos apreendidos não parecem ter vinculação com militância comunista. O jornal "O Ruista", provavelmente vem de Rui Barbosa, anticomunista que inclusive é citado no relatório do Encarregado do Inquérito defendendo o fim do Comunismo. O interessante não é apenas a apreensão das publicações mencionadas, mas o questionamento realizado. Pelo visto, jornais estudantis, pelo simples fato de serem feitos em escolas, poderiam ser considerados material subversivo. E História do Século 20, seria uma prerrogativa subversiva apreciar e estudar História? Nota-se que suscitava receios.

Sua esposa declarou que, mesmo o acusado sendo advogado do sindicato por nove anos, nunca tivera conhecimento de que seu marido militasse no PCB e que as reuniões que ocorriam em sua casa tivessem outro objetivo que não fosse o sindicato.

Que a declarante não pode precisar a época em que foram feitas mencionadas reuniões; que a declarante jamais teve conhecimento ou mesmo desconfiança de que seu marido estivesse envolvido com militantes do Partido Comunista Brasileiro, pois se tal fato fosse de seu conhecimento teria evitado que tal acontecesse. (BRASIL, 1978, p. 270).

O fato de estar participando de reuniões referentes ao sindicato no qual trabalhava, sendo Criciúma conhecida, segundo Celso Martins, como "Vespeiro da Bacia Carbonífera", tendo em vista a militância de esquerda ali atuante, deixava o advogado na mira dos órgãos de repressão.

Segundo o Encarregado do Inquérito, J.S.N. era o membro do PCB responsável pelo setor sindical. Relata que, mesmo em 1972, diferentemente de suas declarações, após um racha administrativo e uma intervenção federal no sindicato, J.S.N. permaneceu no partido. Em resumo, descreve o Encarregado as atividades do réu.

Natural de Santiago/RS, nascido em 1932. [...]
Iniciou sua militância no Partido Comunista Brasileiro no ano de 1970. [...] Membro efetivo do Comitê Municipal do PCB/Criciúma até o ano de 1972, sendo responsável pelo Setor Sindical em virtude de ser advogado do Sindicato dos Mineiros daquela cidade. [...]

Participou de várias reuniões do CM/ Criciúma, duas das quais realizadas em sua residência. [...]

Dava contribuições em dinheiro para o "Partido" [...]

Recebia "Voz Operária”. (BRASIL, 1978, p. 452).

$\mathrm{O}$ Encarregado do Inquérito requereu sua prisão preventiva, por considerá-lo perigoso para a Segurança Nacional. O Ministério Público, entendendo da mesma forma, em parecer, destacou que, tendo em vista as confissões ocorridas na fase do inquérito, o acusado não poderia responder $o$ processo em liberdade.

Nas declarações de fls. 87, confessou seu ingresso no PCB, através de C.M.P. Era integrante do CM/PCB/ Criciúma - SC, como responsável pelo setor sindical. Participou de várias reuniões do $\mathrm{CM} / \mathrm{PCB} / \mathrm{Criciúma} \mathrm{-}$ SC. Recebia exemplares da "Voz Operária”, por intermédio de L.G.B. e W.H.W.H. Dava contribuições mensais, no valor de CR\$50,00, ao PCB, entregando o dinheiro a L.G.B., C.M.P. e W.H.W.H.. Suas atividades e confissão restaram comprovadas pelas declarações de fls. 28, 34, 55, $78,82,103,127$ e 226 , em indiscutível demonstração de periculosidade danosa à Segurança Nacional, não oferecendo este denunciado garantia a instrução criminal nem a segura aplicação da lei penal, se libertado. (BRASIL, 1978, p. 489).

A exceção da declaração de sua esposa, todas as provas nos autos até aquele momento levavam a crer que o acusado realmente fosse membro efetivo do PCB, sendo alguém inclusive instruído, que atuava no setor sindical, influenciando outros possíveis militantes. O advogado de J.S.N., em sua primeira participação no processo, demonstrou, através de documentos, que o acusado, embora possuísse todos os requisitos considerados 
necessários para a liberdade provisória, foi mantido preso pelo Conselho Permanente de Justiça.

O réu, em seu interrogatório judicial, afirmou que foi preso no dia 08 de novembro de 1975, às 17 horas, e levado para Curitiba. Informa que ficou seis dias incomunicável e sua prisão ocorreu da seguinte forma: foi obrigado a entrar numa perua Ford ou Chevrolet, algemado e com óculos escuros, que praticamente o impediam de ver o que ocorria ao seu redor. Esclareceu, contudo, que não sofreu nenhuma lesão física ou moral. De volta a Florianópolis, afirmou que a viagem foi até amistosa, na relação dos policiais com os presos.

Em Florianópolis, ficou um tempo no Batalhão da Polícia Militar, sendo conduzido duas vezes para o Departamento da Polícia Federal, onde assinou suas declarações por medo. Afirmou que nunca havia organizado qualquer reunião do $\mathrm{PCB}$ em sua residência. E que nunca havia lido o jornal "Voz Operária" ou o "Manifesto ao Povo Brasileiro" (BRASIL, 1978, p. 3498).

As declarações de arrependimento aparecem inicialmente em uma petição escrita por ele próprio e dirigida ao Conselho Permanente de Justiça, requerendo o relaxamento de sua prisão. Descreveu as dificuldades pelas quais passou durante sua vida até se formar em Direito e começar a advogar para o Sindicato dos Mineiros em Criciúma.

Busquei sempre o exercício profissional, com amor, honradez, probidade e patriotismo. No entanto por equivocado idealismo, influenciado talvez pelas inquietações e frustrações do mundo contemporâneo, bem como pela falsa idéia de que estava procedendo corretamente e, mais ainda, pela insidiosa manobra de impatriótico envolvimento fui infelizmente aliciado para o Partido Comunista Brasileiro em princípios de 1970. (BRASIL, 1978, p. 2120).

Confessou ter participado do Partido Comunista, mas apenas por ter sido aliciado. Segundo suas declarações, foi convencido a ingressar, tendo sido pessoalmente enganado e, por boa-fé, entrou no partido. Acredita-se que, como advogado que era, e vendo sua situação piorar após cada depoimento, o acusado utilizou-se de uma artimanha para se ver livre das acusações: pôs a culpa de sua militância "subversiva" no próprio comunismo.

Como assim? Ora, o comunismo infiltrase na sociedade como um micróbio, semeando a discórdia e a desordem entre as classes, convencendo as pessoas de que seu papel é ajudar os trabalhadores. Contudo, segundo os doutrinadores anticomunistas, esta "ideologia alienígena" somente queria escravizar o trabalhador, fazendo-o abrir mão de sua liberdade de trabalho e de suas tradições brasileiras, utilizando-se da parcimônia e idealismo de um povo ingênuo que poderia ser facilmente convencido pelos princípios de igualdade pregados pelo Comunismo. A petição continua, repudiando o Comunismo e todas as suas formas de existência:

Contudo por imperativo de consciência, a bem da verdade, do bom senso e da coerência. Logo reconheci meu erro e procurei corrigi-lo, rompendo e repudiando como de fato repudiei e rompi, espontânea, consciente e definitivamente, em fins de 1971, com a mencionada organização ilegal. E assim procedi, porque através de reflexão livre e consciente, consolidada pela confirmação fática e real, acabei concluindo que a ideologia comunista (em qualquer de suas matizes que possa apresentarse), além de incompatível com minha natureza cristã e democrática, violenta, fundamentalmente, desgraçadamente, os mais elementares princípios de independência e liberdade de qualquer povo. (BRASIL, 1978, p. 2122).

Nas petições estão praticamente todos os conceitos presentes no imaginário anticomunista, talvez de modo bastante hábil, recolhendo alguns signos que circulavam entre a sociedade e que, muito provavelmente, também eram compartilhados pelos Juízes Militares. O cristianismo, a democracia, a violência, a independência nacional, a liberdade, com todas as representações próprias a época, completam e demonstram a percepção que possui o acusado dos elementos que compunham o imaginário dos Juízes ao tomar decisões sobre os 
processos contra membros de uma organização comunista.

Como é de conhecimento geral, cada país comunista tem uma interpretação diversa para um mesmo problema, dependendo sempre das circunstâncias e das conveniências do partido relativamente ao povo que deseja subjulgar. Numa só coisa não há divergência, isto é, no propósito totalitarista de impor a doutrina comunista, e, para isso todos os meios são lícitos contanto que a maioria permaneça submissa à minoria dominante. (BRASIL, 1978, p. 2122).

Tentado demonstrar a sua conversão ao modo de ser do regime militar instaurado no Brasil, não poupou elogios ao governo e à segurança que proporcionou ao povo brasileiro. O Brasil seria o exemplo de tranquilidade em um mundo agitado, um exemplo de paz e prosperidade: "[...] o Brasil de hoje, para justo orgulho de todos nós brasileiros, sem qualquer favor ou sofisma, é uma das poucas ilhas de paz, trabalho, progresso e tranqüilidade no agitado oceano universal". (BRASIL, 1978, p. 2123)

Era exatamente assim que o governo instituído vangloriava o Brasil, como um mar de tranquilidade após a Revolução de 1964. Faz o réu o jogo de escrever o que os juízes gostariam de ler. Não deixa de demonstrar uma capacidade perceptiva para escrever exatamente aquilo que os governantes e integrantes da máquina estatal gostariam de ler de alguém que se diz arrependido de ter sido comunista. Como se estivesse nas trevas e foi tocado por uma luz, que o libertou do pensamento totalitário comunista que o impedia de enxergar.

Cita diversas conquistas dos governos Revolucionários: PIS, FGTS, legislação trabalhista e previdenciária, aposentadorias especiais, planos habitacionais e liberdade de imprensa para numerosos jornais existentes. Concluindo, por fim: "[...] e isso nem chega a ser um pálido resumo das medidas que nos dão a certeza de um presente seguro e a esperança não quimérica de um futuro ainda melhor" (BRASIL, 1978, p. 2125).

Tais afirmações, de modo muito evidente, parecem de encomenda para convencer os juízes de que seu comportamento não era mais comunista ou subversivo. Não se vislumbra a hipótese do acusado, como ex-militante do Partido Comunista, não saber que efetivamente havia censura à imprensa. Mas era o plano de defesa: escrever o que os juízes queriam ler.

Finalmente, apresenta um argumento que, inclusive, será utilizado pelos juízes para que estes concluam que não houve tortura e que toda a história de sevícias não passaria de mera invenção, mesmo que, em outro momento, houvesse afirmado que sentira medo de não assinar as declarações datilografadas pelo encarregado do inquérito.

Por isso mesmo, surpreende-me as alegações de alguns presos que se dizem vítimas de torturas e que seus depoimentos foram obtidos através de coação física ou moral. E, a surpresa transformou-se em repulsa, quando, esses mesmos presos procuraram insinuar que também eu deveria proclamar a denúncia de torturas como matéria de defesa. (BRASIL, 1978, p. 2126).

Ao final desta petição requer apenas a juntada das declarações, não pugnando nem ao menos pelo relaxamento de sua prisão, talvez para reforçar a defesa de que pretendia apenas apresentar suas verdades aos juízes para que não o condenassem por ter sido ingênuo e convencido de que o Comunismo seria viável.

Em nova carta encaminhada ao Conselho, J.S.N. relata como é difícil não ser seduzido pelo Comunismo numa época turbulenta da História mundial, explicando com mais detalhes o porquê de ter sido aliciado pelo Partido Comunista Brasileiro.

Num mundo rodeado de conflitos em escala internacional, em problemas raciais, situações beligerantes, inflação mundial, corrida armamentista, criação de blocos econômicos, comerciais e militares, tudo no mais tenso clima internacional, onde se defrontam, numa luta incessante, duas ideologias contrárias e radicalmente opostas a democracia, dos países livres, e o comunismo marxista-leninista, dos países totalitários - torna-se difícil e, por vezes impossível, mesmo para pessoas de relativo nível cultural, 
discernir, dentro deste contexto, o que é certo, o que é bom, o que serve para nossa pátria, nosso povo e até para nós mesmos [...]. (BRASIL, 1978, p. 2323).

Novamente percebe-se que todos os elementos do anticomunismo estão presentes na fala do acusado: a guerra fria, a democracia liberal contra o comunismo totalitário, o bem representado pelo capitalismo e, consequentemente, o mal representado pelo comunismo.

Afirmou ter sido induzido a participar de uma reunião do $\mathrm{MDB}$, durante a qual percebeu, de forma surpreendente, que se tratava de uma reunião do $\mathrm{PCB}$, tendo em vista o modo como se comportavam os participantes, bradando palavras de ordem da seguinte estirpe contra o governo: “[...] revogação do AI-5, do Decreto ${ }^{\circ}$ 477, defesa das liberdades democráticas, reforma agrária; arrocho salarial; anistia política; derrubada da ditadura militar; insucesso da política econômica do governo no combate à inflação etc."; destacou principalmente o linguajar utilizado pelas pessoas, pugnando pela desmoralização do governo em uma “[...] arenga impatriótica, demagógica e contrária à segurança, aos interesses nacionais, à tradição do povo brasileiro e às minhas próprias conviç̧ões democráticas" (BRASIL, 1978, p. 2323).

Posteriormente, teria sido distribuído um embrulho aos presentes da reunião, o qual posteriormente constatou ser o jornal oficial do PCB, "Voz Operária", tendo sua revolta sido imediata:

Indignado pela má-fé nos propósitos
daquelas pessoas, neguei-me
voluntariamente e conscientemente a
participar de novas reuniões, inclusive
advertindo na ocasião o meu aliciante
que, em hipótese alguma, minhas
convicções eram compatíveis ou
coniventes com qualquer ideologia
estranha e contrária aos interesses do
povo brasileiro. Pois sou contra qualquer
forma de organização totalitária
especialmente as de tendências
comunistas. (BRASIL, 1978, p. 2123).

Mais uma vez deve-se compreender tratarse de uma estratégia de defesa de alguém submetido a uma prisão arbitrária e sob o notório risco de tortura. Isso fica nítido porque deliberadamente omite ter participado de muito mais do que apenas uma reunião, já que informou ter permanecido filiado ao PCB desde o início de 1970 até fins de 1971. Fez ainda um apelo à juventude e ao povo brasileiro:

Quero também fazer um apelo à juventude e ao povo brasileiro, para que não se deixem envolver, para que não se deixe iludir por qualquer propaganda, mal orientada, comprometedora e de má-fé, daqueles que, embora rotulados de "progressistas", "avançados", "democratas", são na verdade contrários aos interesses nacionais, inimigos do Brasil e do seu povo, ridículos serventuários do comunismo internacional, que tudo fazemparadestruiraliberdade,oprogresso, e a segurança e o desenvolvimento do país, na diabólica tentativa de sepultar definitivamente nossas instituições democráticas e cristâs. (BRASIL, 1978, p. 2325).

Utilizou elementos religiosos - "diabo", "cristãs" - e o discurso governamental para tentar convencer os juízes de sua inocente participação de sua nova conduta, que o tornavam um homem de bem. $\mathrm{O}$ acusado utilizou o próprio imaginário dos juízes e da Justiça Militar da época para pleitear sua absolvição. O crime cometido, pior do que formar uma organização partidária ilegal, era ser comunista. Como estava em jogo a criminalização do pensamento, percebeu que o menor problema estava na organização clandestina de um partido, mas sim pensar de acordo com o Partido Comunista. Suas mensagens e cartas, aparentemente, redundaram em seu benefício, pois foi posto em liberdade provisória em 22 de setembro de 1976. Todas as testemunhas confirmaram que ele possuía todos os requisitos necessários para ser considerado um homem digno: bom chefe de família, trabalhador, honrado e desvinculado de participação política.

Nas alegações finais, o Ministério Público, de forma lacônica, elenca o acusado entre os culpados, requerendo a condenação a dois anos de reclusão. De sua parte, o defensor de J.S.N. afirmou que o acusado, em interrogatório, desmentiu as informações assinadas durante o inquérito policial, 
novamente referindo-se ao medo que sentiu.

Entretanto, o acusado prestando declarações em juízo, às fls 1472/1476, confirmam, digo, não confirmam as constantes em fls. 114/116 do inquérito. Em Juízo, o acusado após falar das razões pelas quais assinou as declarações do inquérito, informou que nunca esteve em qualquer reunião comunista ou pró reorganização do $\mathrm{PCB}$, negando assim, não só as declarações como também a acusação. Os co-réus por sua vez não confirmaram em juízo aquilo a que lhes atribuiu no inquérito. (BRASIL, 1978, p. 3307).

Destaque-se a contradição entre as cartas do acusado, informando no inquérito que não participou de nenhuma reunião do $\mathrm{PCB}$, posteriormente admitindo que participou de reuniões e que foi filiado ao partido do início de 1970 até fins de 1971, depois, que participou de apenas uma reunião e, por fim, veio seu advogado reforçar que nunca participara de qualquer reunião.

$\mathrm{Na}$ audiência final, o representante do Ministério pediu a absolvição de J.S.N., sem uma fundamentação mais profunda, pelo menos na resumida ata de audiência, alegando apenas que analisara melhor os autos.

$\mathrm{Na}$ sentença, foi absolvido pelo fato de ter se afastado da política a tempo de não participar da reorganização do PCB: "[...] enquanto J.S.N., as fls. 116, alega que 'em agosto de 1971, resolveu abandonar o partido comunista, não mais participando de qualquer reunião do mesmo"' (BRASIL, 1978, p. 3487). Os magistrados afirmaram considerar que diversos acusados, incluindo J.S.N., não chegaram a fazer parte do comitê estadual do partido comunista em Santa Catarina, ou desempenhado atividades para a reorganização do partido comunista, ou propagado ideia neste sentido, a ponto de causar perigo ou grave ameaça à segurança nacional, sendo o acusado absolvido por unanimidade.

\section{Considerações}

Ao final do presente artigo, é importante fazer alguns destaques. Aos juízes coube o trabalho de montar toda uma engenharia jurídica, de modo a assegurar que o inquérito fosse apresentado como se estivesse dentro de todas as normas processuais. Pouco adiantou as declarações de testemunhas de acusação negando ter presenciado as confissões e afirmando que somente assinaram os documentos gerados pelos depoimentos após os depoimentos já terem sido realizadas. Para os juízes, embora sem nenhuma testemunha além do próprio interrogador da polícia, tais confissões valiam como prova.

Consideravam que, apesar não haver confissão de participação no PCB por parte dos acusados na fase do interrogatório judicial, existiam relações de amizade entre eles e admissão de que se envolviam em reuniões políticas, as quais não teriam a guarida de um partido oficial. O silogismo é que, sem uma tutela oficial, não pode ocorrer discussão política, gerando a suspeição de que algo pode estar sendo escamoteado. Como o comunista aparece como um ser ardiloso, os acusados foram condenados por sua infiltração em diversos meios da sociedade, com o intuito de difundir seus ideais subversivos. Novamente verifica-se que a questão do tipo penal, da reorganização de partido declarado ilegal, era posta em segundo plano, enquanto o mais importante era verificar pelas provas dos autos se eram os acusados comunistas ou não.

Os réus, segundo é possível concluir pelas evidências, foram sequestrados, deixados incomunicáveis, torturados perante o inquérito policial e deixados presos acima do prazo legal, muitas das vezes doentes. Foram mantidos presos por alguns meses ou até anos; e os que foram condenados apenas obtiveram a liberdade com a Lei da Anistia de 1979.

Os réus foram introduzidos em um emaranhado estatal jurídico, criado para legitimar um regime que se pretendia legalmente constituído. A Justiça Militar e todo o aparato repressor, de certo modo, compartilhavam crenças e valores que não se restringiram a um regime de exceção e são um amplo universo a ser explorado pelos historiadores, pois o resultado de suas ações, para além dos sofrimentos e mortes causados, também originou vozes dispersas e um conjunto de práticas que deixou marcas na cultura política brasileira contemporânea. 


\section{Notas}

1 A grafia de todos os trechos citados de documentos da época foi mantida sem correções; por isso, desvios quanto à norma culta devem ser desconsiderados.

2 O PCB fundado em 1922. Após um longo período de clandestinidade, conseguiu um breve momento de existência legal entre 1945 e 1947, quando foi novamente posto na ilegalidade. Atuou, desde então, junto a movimentos de base, principalmente em sindicatos operários e camponeses. Em 1964, quando ocorreu o golpe militar, vários militantes do partido, sob diversas formas, atuavam na sustentação ao governo João Goulart (CENTRO, 2009)

3 "Art. 59 - Durante as investigações policiais o indiciado poderá ser preso, pelo Encarregado do Inquérito até trinta dias, comunicando-se a prisão à autoridade judiciária competente. Este prazo poderá ser prorrogado por uma vez, mediante solicitação fundamentada do Encarregado do Inquérito a autoridade que o nomeou" (BRASIL, 1969a).

4 “Art. $13 \$ 2^{\circ}$ - Os Conselhos Permanentes de Justiça serão constituídos do auditor, de um oficial superior, como presidente, e de três oficiais até o pôsto de capitão ou capitão-tenente" (BRASIL, 1969c).

$5 \mathrm{O}$ processo criminal militar contra 42 membros ou acusados de serem membros do Partido Comunista Brasileiro, encontra-se arquivado na seção de arquivos, órgão subordinado à Diretoria de documentação e divulgação do Superior Tribunal Militar, localizado no endereço: Setor de Autarquias Sul, Praça dos Tribunais Superiores, Cep: 70098900, Brasília, Distrito Federal, estando assim designado: BRASIL. Superior Tribunal Militar. Apelação $\mathrm{n}^{\circ}$ 42.031. Apelantes: O Ministério Público Militar junto à Auditoria da 5a CJM e outros. Apelada: a Sentença do Conselho Permanente de Justiça da Auditoria da 5a CJM, de 10 de fevereiro de 1978, no processo $n^{\circ} 749$.

6 Ato que dá início a uma ação penal.

7 Ato em que o Juiz literalmente recebe fisicamente o documento que dá início à ação penal, a denúncia, verificando se este documento cumpre todos os requisitos legais para que a ação criminal se inicie, e verificando também se realmente existem indícios de crime contra os réus, de acordo com as provas que acompanham este documento. No caso do juiz receber a denúncia, a ação penal é iniciada.

8 Os nomes foram colocados apenas com suas iniciais, pois este pesquisador não possui autorização da família nem do Superior Tribunal Militar para divulgar dados pessoais dos acusados.

9 Após comparecer à sede do DOI-CODI no começo da manhã do dia 25 de outubro de 1975 para prestar depoimento sobre sua suposta ligação com o Partido
Comunista Brasileiro, o jornalista Wladimir Herzog foi encontrado enforcado, no final da tarde, em uma das celas das dependências da instituição em São Paulo. Segundo a versão oficial do II Exército (comandado pelo General Ednardo D’Ávila Mello), ratificada por IPM, ele teria se suicidado com o próprio cinto. Entretanto, Clarice, Ivo e André Herzog, mulher e filhos da vítima, moveram ação cível contra o Governo em abril de 1976, responsabilizando-o por prisão ilegal, tortura e morte. A sentença foi julgada procedente no dia 27 de outubro de 1978, condenando a União a danos morais e materiais (CASO, 2007).

\section{Referências}

ALVES, Maria Helena Moreira. Estado e oposição no Brasil: 1964-1984. Bauru: Edusc, 2005.

AS CRÍTICAS do senador Passarinho à censura. O Estado, Florianópolis, 4 nov. 1975. p. 3.

BANCO do Brasil. Edital. Seleção de auxiliar de escrita. O Estado, Florianópolis, 4 nov. 1975. p. 9.

\section{BRASIL. Constituição da República Federativa} do Brasil de 1967. Disponível em: <http://www. presidencia.gov.br/legislacao $>$. Acesso em: 2 jul. 2008.

\section{BRASIL. Decreto-lei $\mathbf{n}^{\circ}$ 898, de 29 de setembro de}

1969a. Define os crimes contra a segurança nacional, a ordem política e social, estabelece seu processo e julgamento e dá outras providências. Disponível em: $<$ http://www.senado.gov.br/legislacao $>$. Acesso em: 5 nov. 2007.

BRASIL. Decreto $\mathbf{n}^{\mathbf{1}} \mathbf{1 0 0 2}$, de 21 de outubro de 1969b. Código de Processo Penal Militar. Disponível em: http://www.planalto.gov.br/ccivil/Decreto-Lei/ Del1002.htm. Acesso em: 3 dez. 2008.

BRASIL. Decreto-lei no 1.003 , de 21 de outubro de 1969c. Lei da Organização Judiciária Militar. Disponível em: http://www.senado.gov.br/ legislação. Acesso em: 15 out. 2008.

BRASIL. Superior Tribunal Militar. Apelação $\mathbf{n}^{\mathbf{0}}$ 42.031. Apelantes: O Ministério Público Militar junto à Auditoria da 5a CJM e outros. Apelada: a Sentença do Conselho Permanente de Justiça da 
Auditoria da 5a CJM, de 10 de fevereiro de 1978, no processo $\mathrm{n}^{\circ} 749$, p. 172.

BRASIL. Lei ${ }^{\circ} \mathbf{6 . 6 8 3}$, de 28 de agosto de 1979 . Concede anistia e dá outras providências. Disponível em: http://www.planalto.gov.br/ccivil_03/leis/ L6683.htm. Acesso em: 14 dez. 2008.

BRASIL. Tribunal Regional Eleitoral. Resenha Eleitoral: Nova Série Eleição Catarinense 1945 1998. Disponível em: http://www.tre-sc.gov.br/site/ fileadmin/arquivos/eleicoes/eleicoes2006/resenha_ historica.pdf resenha eleitoral do tre sc.

CAMARA dos Deputados. Biblioteca Digital. Dados estatísticos : eleições federais e estaduais realizadas no Brasilem 1974. Disponível em $<\mathrm{http}$ :// bd.camara.leg.br/bd/handle/bdcamara/13016> Acesso em 14 ab. 2006.

CASO Herzog: União é culpada no caso Herzog. Banco de dados da Folha. Disponível em <http:// almanaque.folha.uol.com.br/brasil_28out1978. htm>. Acesso em: 12 dez. 2008.

CENTRO de Pesquisa e Documentação de História Contemporânea do Brasil. Partido Comunista Brasileiro. Dicionário Histórico-Biográfico Brasileiro. 2009, [s. p.]. Disponível em http:// www.cpdoc.fgv.br/nav_historia/htm/anos20/ev_ quesocial_pcb.htm. Acesso em: 3 mar. 2009.

COGAN, Arthur. Crimes contra a segurança nacional: comentários, legislação, jurisprudência. São Paulo: Rev. dos Tribunais, 1976. p. 81.

COSTA, Darci. Cinema. O Estado, Florianópolis, 4 nov. 1975. p. 12.

D’ARAÚJO, Maria Celina; CASTRO, Celso. Dossiê

Geisel. Rio de Janeiro: FGV, 2002.
FIGUEIRA é todo entusiamo contra o Flu. O Estado, Florianópolis, 4 nov. 1975.

FRANCO enfermo há 18 dias, resiste consciente. O Estado, Florianópolis, 4 nov. 1975. p. 1.

GEISEL recebe Konder Reis amanhã. O Estado, Florianópolis, 4 nov. 1975. p. 1.

GOVERNAR é encurtar distâncias. O Estado, Florianópolis, 4 nov. 1975. p. 11.

IR tem desconto padrão. O Estado, Florianópolis, 4 nov. 1975. p. 1.

ISABEL doente é hospitalizada. O Estado, Florianópolis, 4 nov. 1975. p. 1.

JUIZ Militar decreta prisão de 9 acusados por subversão. O Estado, Florianópolis, 8 nov. 1975. p. 3.

JUSTIÇA militar em São Paulo absolveu mais 6. O Estado, Florianópolis, 9 nov. 1975. p. 11.

JUSTIÇA Militar segue acusando 36 por atos terroristas. O Estado, Florianópolis, 7 nov. 1975. p. 11.

LPO comanda o espetáculo e põe philips em cena. O Estado, 7 nov. 1975. p. 15.

MARTINS, Celso. Os quatro cantos do sol: Operação Barriga Verde. Florianópolis: Editora da UFSC: Fundação Boiteux. 2006.

NO BALNEÁRIO Camburiu luxo e conforto pelo menor preço. O Estado, Florianópolis, 7 nov. 1975. p. 10.

PROMOTOR se pronuncia em processo contra exdeputado. O Estado, Florianópolis, 4 nov. 1975. p. 9. 